\author{
K. Pańcikiewicz*, A. Zielińska-Lipiec, E. Tasak \\ AGH University of Science and Technology, Faculty of Metals Engineering and Industrial \\ Computer Science, Department of Physical and Powder Metallurgy, \\ 30-059 Cracow, Poland \\ *krzysztof.pancikiewicz@agh.edu.pl
}

\title{
CRACKING OF HIGH-STRENGTH STEEL WELDED JOINTS
}

\begin{abstract}
Fracture evaluation of welded joints in high-strength steels, with bainitic and martensitic structures, is presented and cracking mechanisms discussed. Hot cracks or microcracks formed during welding are further expanded as cold cracks on cooling. The cause of cracking is shown to be low temperature of weld solidification and deformation-induced contraction. Hydrogen can also be an important factor in this cracking.
\end{abstract}

Key words: hot cracking, cold cracking, hydrogen cracking, 7CrMoVTiB10-10 welded joint

\section{INTRODUCTION}

High-strength steels are one of the most widely used construction material in the world. They are characterized by higher mechanical properties than carbon steels, ensured by appropriate chemical compositions and manufacturing technology. Low carbon content provides good formability and weldability. Alloying elements such as copper, titanium, vanadium, and niobium are added for strengthening purposes. According to the Hall-Petch relationship, decrease of the grain size improves mechanical properties. Due to proper thermo-mechanical treatments results in structures such as ferrite, pearlite, bainite or martensite. The correct microstructure cause the optimal combination of high strength and ductility, better impact toughness, improved corrosion and fatigue resistance. Advantages of high-strength steels are noticed by increasing-interest of ship building, automotive, gas and power energy industries. Thin walls reduce the total weight of a construction. For joining high-strength steels, manual and automatic welding processes (Manual Metal Arc Welding, Gas Metal Arc Welding, Flux Cored Arc Welding, Gas Tungsten Arc Welding, Submerged Arc Welding) are used. There is then a need to meet the appropriate welding procedures. The complex chemical composition and external conditions influence the susceptibility to cracking during and after welding. Additionally, quenched and tempered steels are thought to be sensitive to hydrogen degradation [1-9]. 


\section{MATERIALS AND EXPERIMENTAL PROCEDURES}

Chemical composition of the investigated materials are shown in Table 1. 7CrMoVTiB10-10 (T24) is a low-alloy bainitic steel used in membrane walls of supercritical power plants boilers. S890QL1 is often used in heavy-lifting industries and is subjected to dynamically loaded environment with a high number of required loading cycles.

Table 1. Chemical composition of steels (control analysis) [10, 11]

\begin{tabular}{|c|c|c|c|c|c|c|c|c|c|}
\hline \multirow{2}{*}{ Steel grade } & \multicolumn{9}{|c|}{ Chemical composition, wt \% } \\
\hline & $\mathrm{C}$ & $\mathrm{Mn}$ & $\mathrm{Si}$ & $\mathrm{Cr}$ & Mo & $\mathrm{V}$ & $\mathrm{Ti}$ & $\mathrm{B}$ & Others \\
\hline 7CrMoVTiB10-10 & $\begin{array}{l}0.05 \\
\div \\
0.10\end{array}$ & $\begin{array}{l}0.30 \\
\div \\
0.70\end{array}$ & $\begin{array}{l}0.15 \\
\div \\
0.45\end{array}$ & $\begin{array}{c}2.20 \\
\div \\
2.60\end{array}$ & $\begin{array}{l}0.90 \\
\div \\
1.10\end{array}$ & $\begin{array}{c}0.20 \\
\div \\
0.30\end{array}$ & $\begin{array}{l}0.05 \\
\div \\
0.10\end{array}$ & $\begin{array}{c}0.0015 \\
\div \\
0.0070\end{array}$ & $\begin{array}{l}\mathrm{P} \leq 0.020 \\
\mathrm{~S} \leq 0.010 \\
\mathrm{~N} \leq 0.010 \\
\mathrm{~A} \mathrm{l} \leq 0.020\end{array}$ \\
\hline S890QL1 & $\begin{array}{c}\leq \\
0.20\end{array}$ & $\begin{array}{c}\leq \\
1.70\end{array}$ & $\begin{array}{c}\leq \\
0.80\end{array}$ & $\begin{array}{c}\leq \\
1.50\end{array}$ & $\begin{array}{c}\leq \\
0.70\end{array}$ & $\begin{array}{c}\leq \\
0.12\end{array}$ & $\begin{array}{c}\leq \\
0.05\end{array}$ & $\begin{array}{c}\leq \\
0.0050\end{array}$ & $\begin{array}{r}\mathrm{P} \leq 0.020, \\
\mathrm{~S} \leq 0.010, \\
\mathrm{~N} \leq 0.015, \\
\mathrm{Cu} \leq 0.50 \\
\mathrm{Nb} \leq 0.06 \\
\mathrm{Zr} \leq 0.15\end{array}$ \\
\hline
\end{tabular}

Multi-bead butt weld in a 7CrMoVTiB10-10 steel tube (OD $42.4 \mathrm{~mm} \times 7.1 \mathrm{~mm}$ ) was made by Gas Tungsten Arc Welding (141 process according to EN ISO 4063 [12]). Multibead plate-to-tube (30 and $45 \mathrm{~mm}$ thickness) butt-joint of S890QL1 steel were made by Gas Metal Arc Welding (135 process according to EN ISO 4063 [12]).

Microstructures of the base materials, heat affected zone (HAZ) and welds were examined using a Leica Light Microscope (LM). Surface morphology and fractographic character were examined by a Stereoscan 120 Scanning Electron Microscope (SEM). Hardness measurements were performed by the Vickers method on a Zwick/Roell ZHU 187,5 universal hardness tester.

\section{CRACKING: RESULTS AND ANALYSIS}

One of the first problem during welding of membrane wall panels made by 7CrMoVTiB10-10 steel was longitudinal hot cracks, Fig. 1. Reduction of welding speed to $0.7 \mathrm{~m} / \mathrm{min}$ solve this problem [13]. Unfortunately, this steel is induced to hot microcrack formation in the crater of weld. Figure 2 shows an example of a crater crack (104 imperfection according to EN ISO 5817 [14]) in butt weld of a tube. On the root of the weld surface cracks with length below $0.5 \mathrm{~mm}$ were observed, out of the resolving power of classical NDT methods. As a consequence of this defect, can cold cracks were initiated and propagated. 

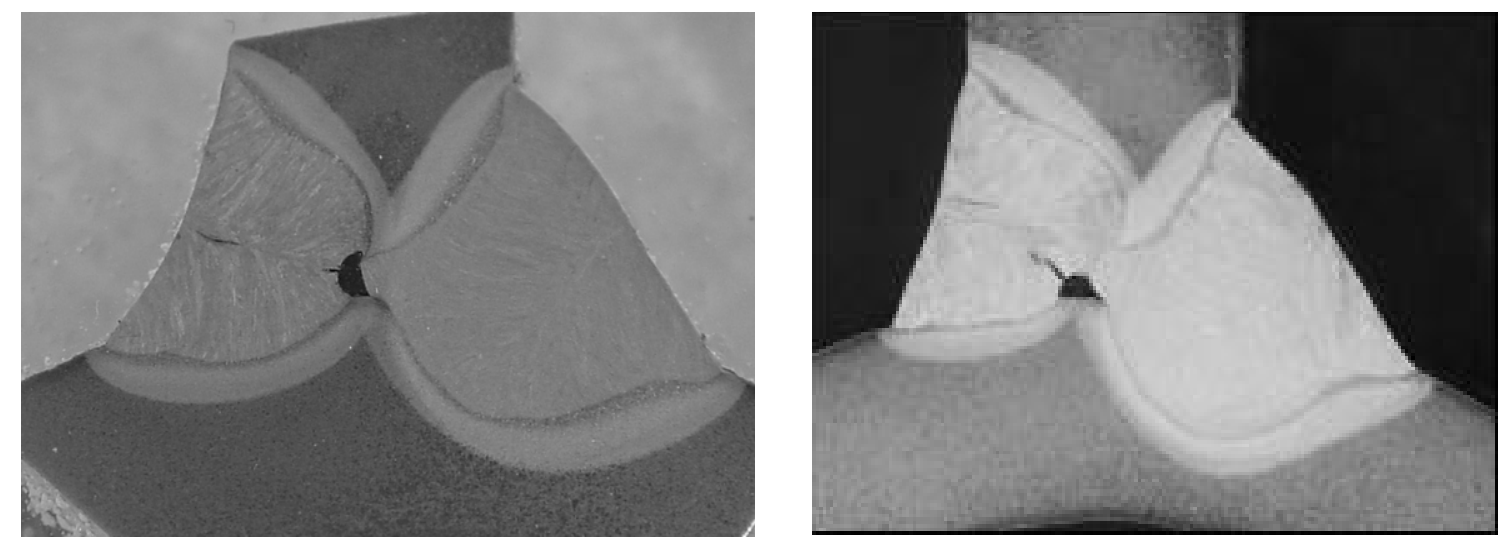

Fig. 1. Hot cracks on the 7CrMoVTiB10-10 steel welds made by Submerged Arc Welding process [13, 15]

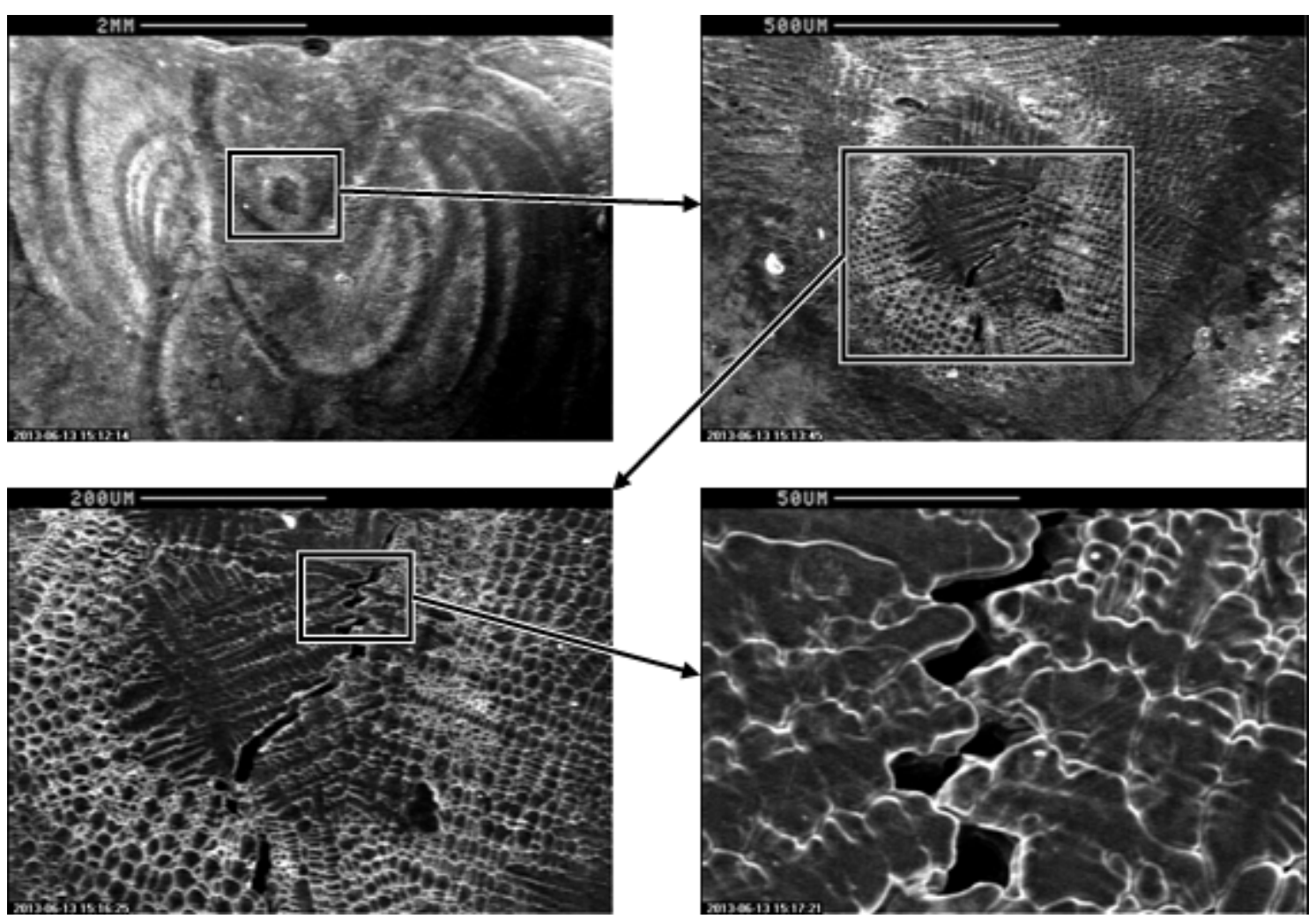

Fig. 2. Hot microcracks in crater of 7CrMoVTiB10-10 steel weld made by Gas Tungsten Arc Welding process (SEM, not etched)

Figure 3 shows a part of cold crack fracture, exposed during pressure testing. Detailed analysis of the most probable beginning of cracking in the region of the root revealed the presence of small imperfections in the form of hot microcracks of branched character and a depth of less than $0.15 \mathrm{~mm}$. They are so-called "spider veins". 


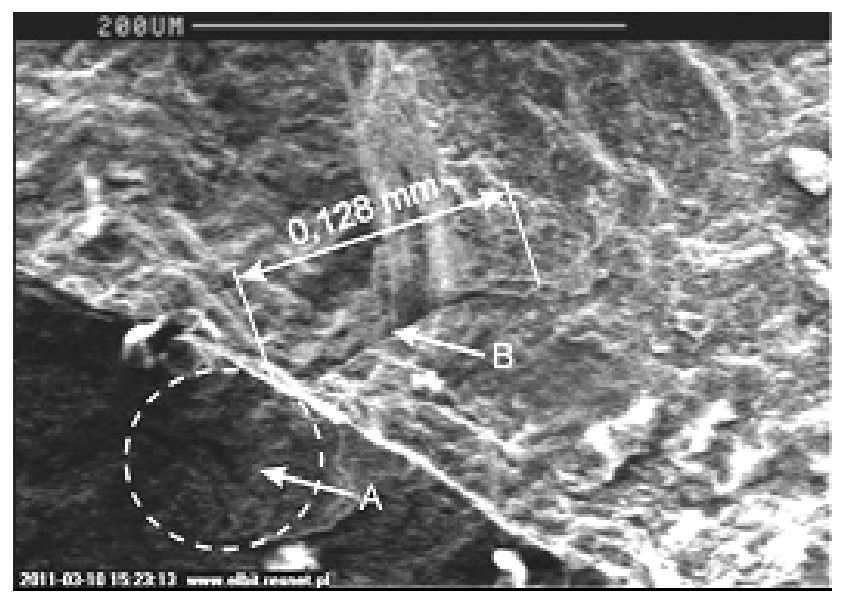

Fig. 3. Most probable place of crack initiation in weld root (crater). A - microcracks in crater ("spider veins"), $\mathrm{B}-$ hot microcrack in root weld. Welding by Gas Tungsten Arc Welding process (SEM) [16]
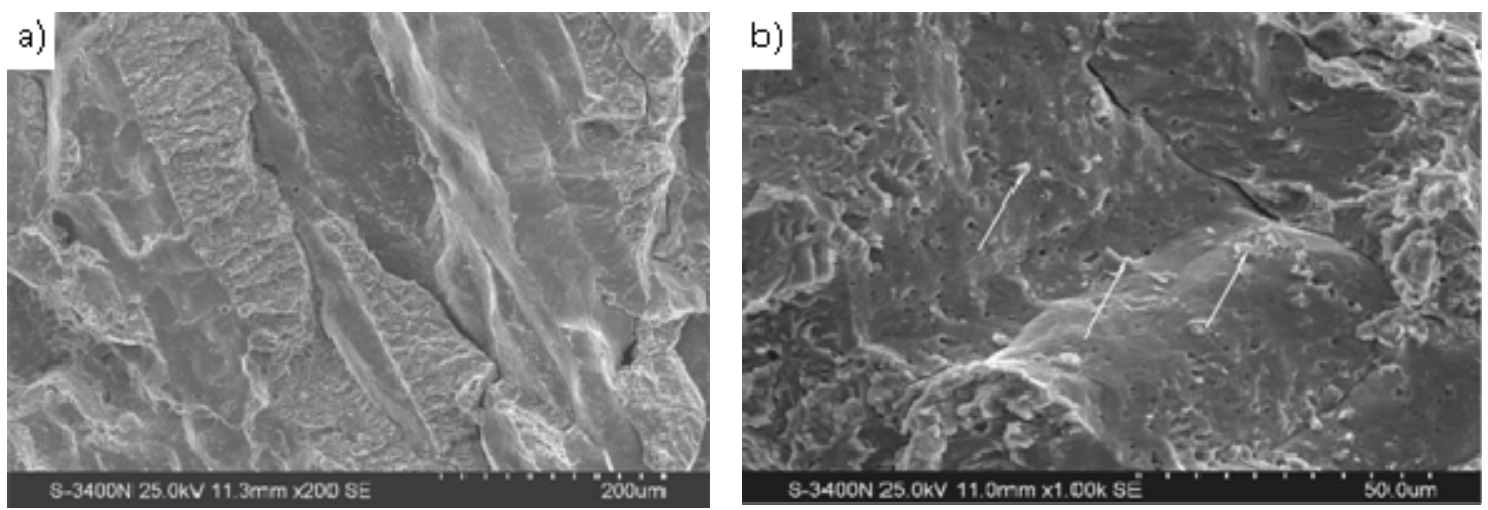

Fig. 4. Morphology of cold crack in 7CrMoVTiB10-10 steel weld metal made by the Submerged Arc Welding process: a) intercrystalline and transcrystalline character; b) intercrytalline character (arrows show brittle broken-out sections) [13]

The reason for the increased susceptibility to hot cracking can be large BTR (Brittle Temperature Range). BTR is the temperature range during the solidification of the weld with only minimal plasticity. According to J. Adamiec [17], Brittle Temperature Range in $7 \mathrm{CrMoVTiB} 10-10$ steel is $190^{\circ} \mathrm{C}\left(1413^{\circ} \mathrm{C}-1223^{\circ} \mathrm{C}\right)$. For example, ductility recovery temperature of $0.17 \% \mathrm{C}$ non-alloy carbon steel in equilibrium conditions is higher- about $272^{\circ} \mathrm{C}\left(1495^{\circ} \mathrm{C}\right)$.

Hot cracks, initiated in this manner, evolve as intercrystalline and transcrystalline cold cracks (Fig. 4a). Characteristic of hydrogen assisted cold cracking are brittle broken-out sections from a neighbouring grain surface, in intercrystalline fracture (Fig. 4b). A similar situation was observed in S890QL1 steel welded joints. Fig. 5 shows macrophotographs of multi-bead welded joints with longitudinal and transverse cracks. 


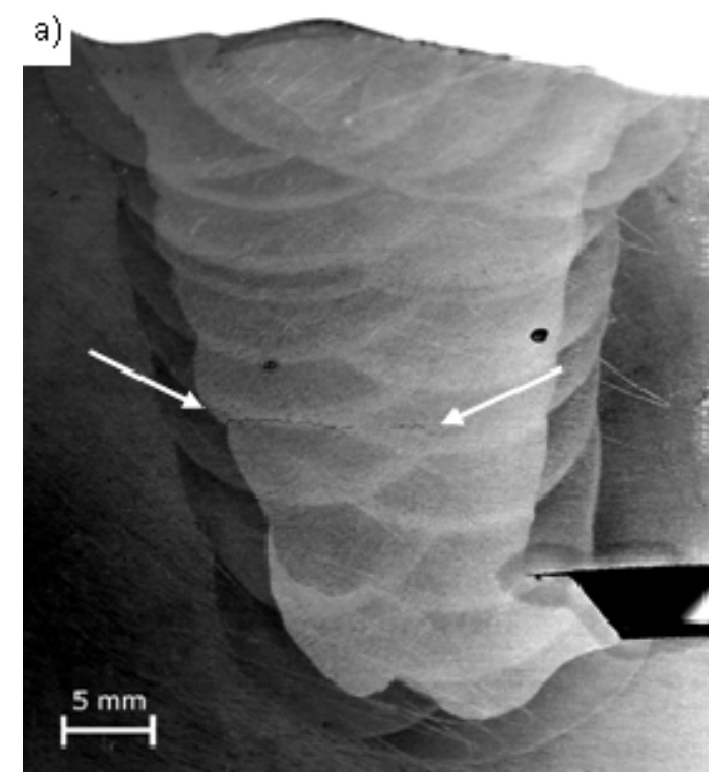

c)



$\stackrel{5 \mathrm{~mm}}{\longmapsto}$

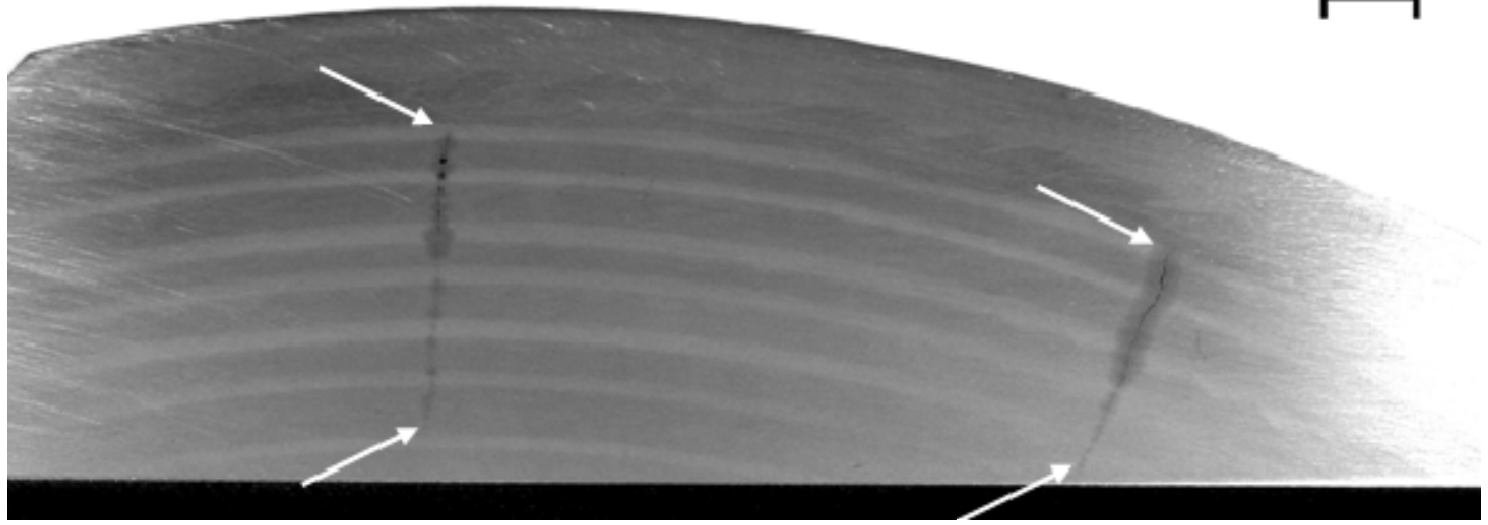

Fig. 5. a) transverse cracks, b-c) longitudinal cracks in S890QL1 steel multi-bead weld made by Gas Metal Arc Welding process

Microscopic examination of polished specimens revealed complex character of discontinuities (Figs. 6a, b and 7a). Nital etching revealed the cracks to have both intercrystalline (Figs. 6c, d, e, 7b, c, e, g) and transcrystalline character (Figs. 6f, 7d). Transverse cracks penetrated several beads of welds and CGHAZ (Coarse Grain Heat Affected Zone). 


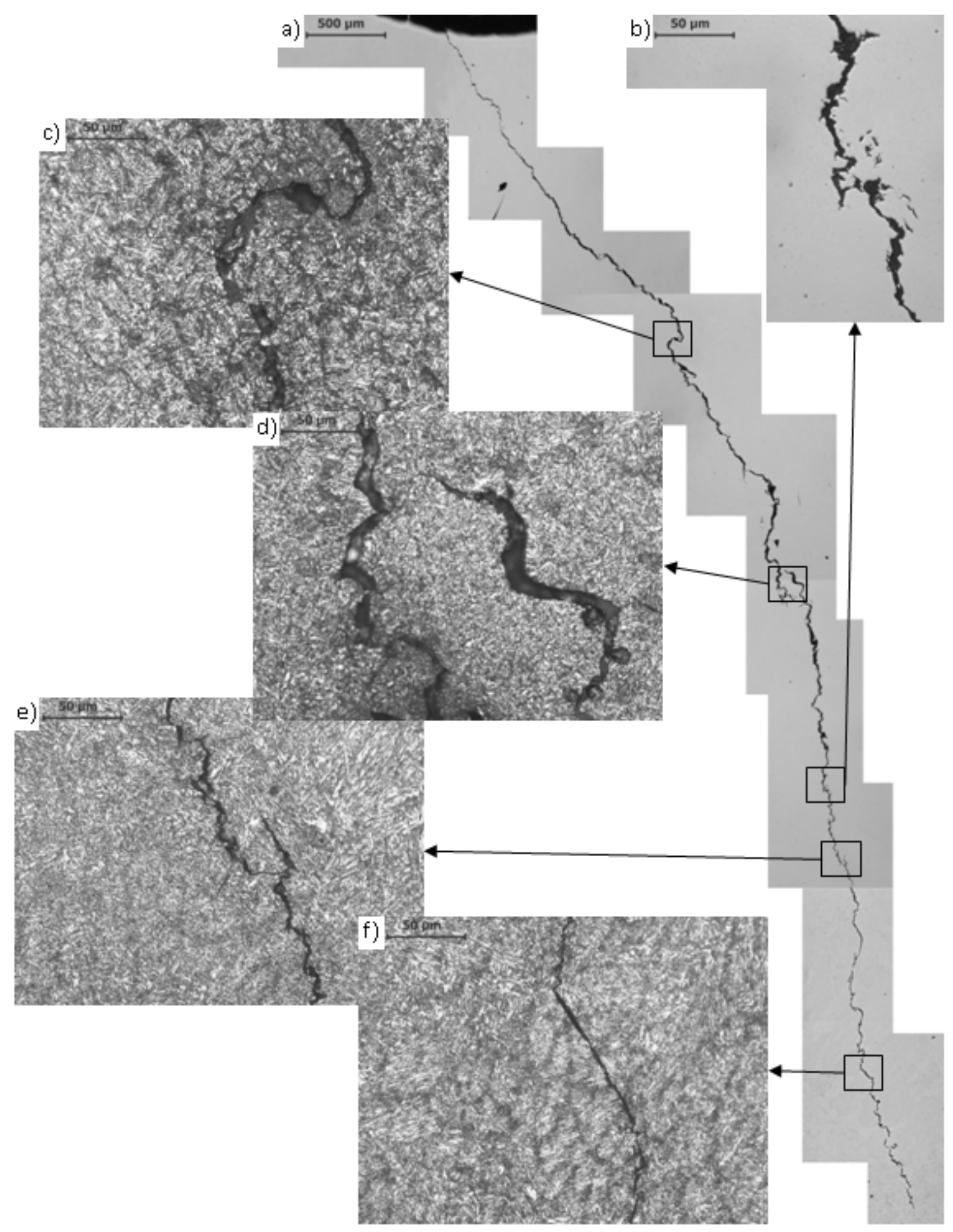

Fig. 5. Longitudinal crack in a multi-bead weld made by Gas Metal Arc Welding process: a-b) LM, not etched, c-f) LM, nital etched 


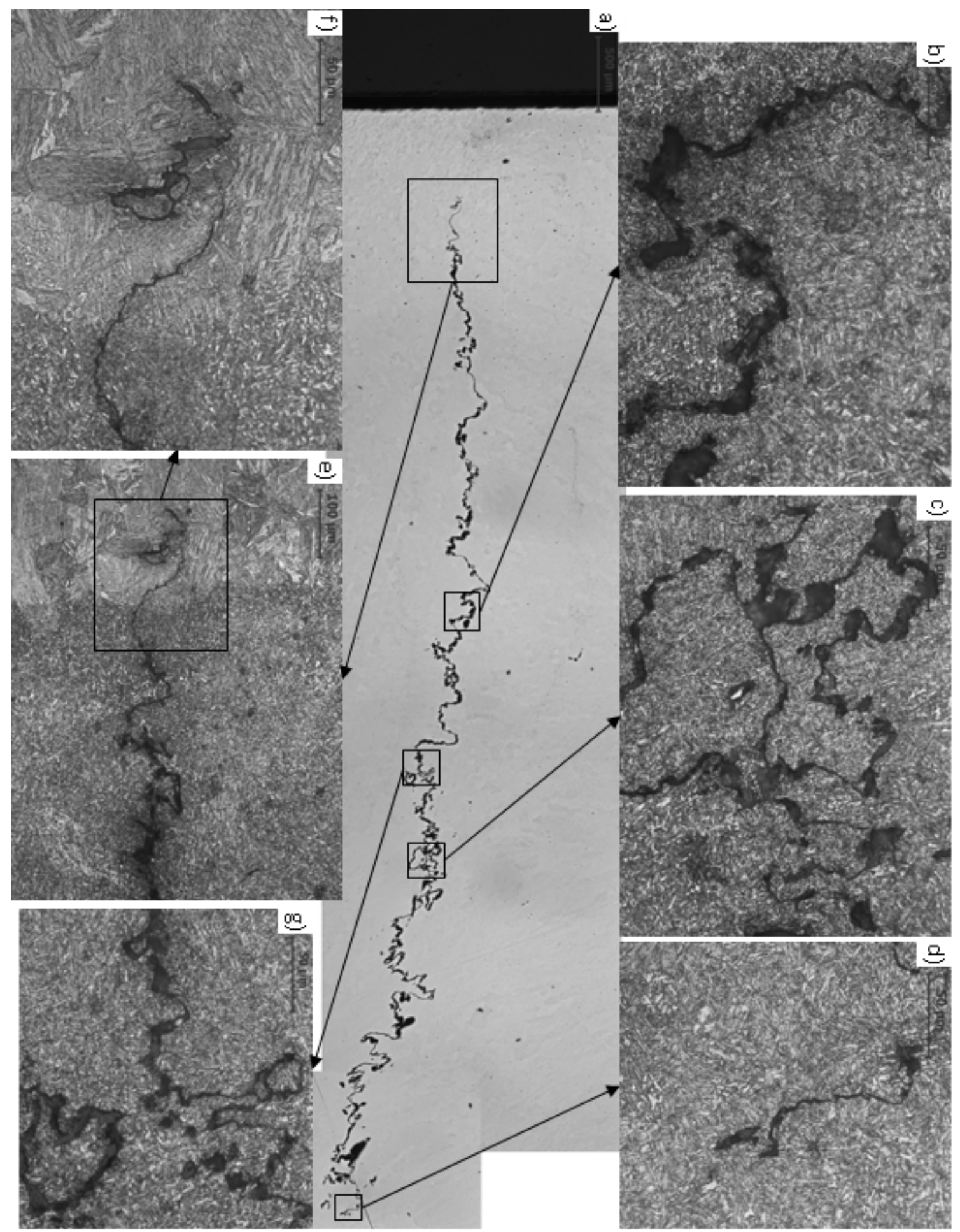

Fig. 6. Transverse crack in a multi-bead weld made by Gas Metal Arc Welding process: a) LM, not etched, b-g) LM, nital etched

Fracture analysis of S890QL1 weld metal crack shows similar character to weld metal cracks in 7CrMoVTiB10-10 steel. Fig. 8a present intercrystalline and transcrystalline character of a delayed cold crack, with brittle broken-out intercrystalline sections (Fig. 8b). 

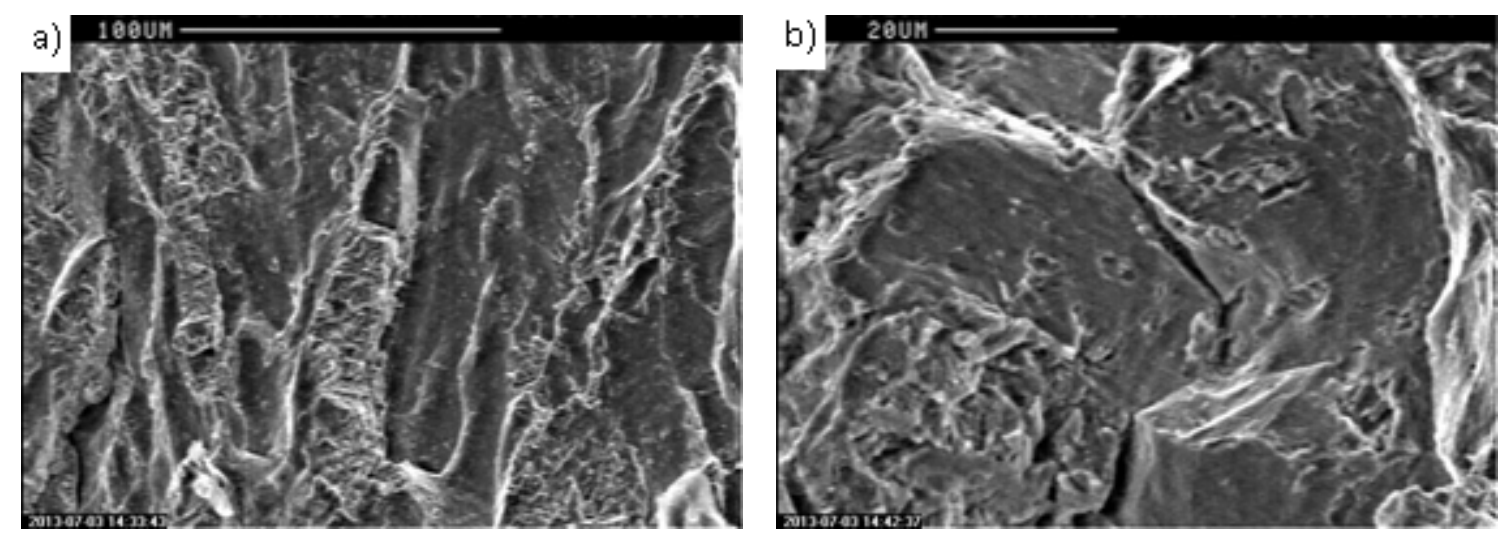

Fig. 8. Morphology of cold crack in S890QL1 steel weld metal: a) intercrystalline and transcrystalline character; b) intercrytalline and ductile character

In the case of these steels diffusible hydrogen content may also be important. The adsorbed hydrogen diffuses into the metal matrix and recombines from atomic form to molecular form and contributes to crack formation. A similar situation may occur when consumable materials are moist. The authors' experience has shown that even low diffusible hydrogen content changes the character of fracture. After cathodic hydrogen charging and tensile testing, fracture of 7CrMoVTiB10-10 weld showed transcrystalline character of cold crack with "fish eyes" (Fig. 9).

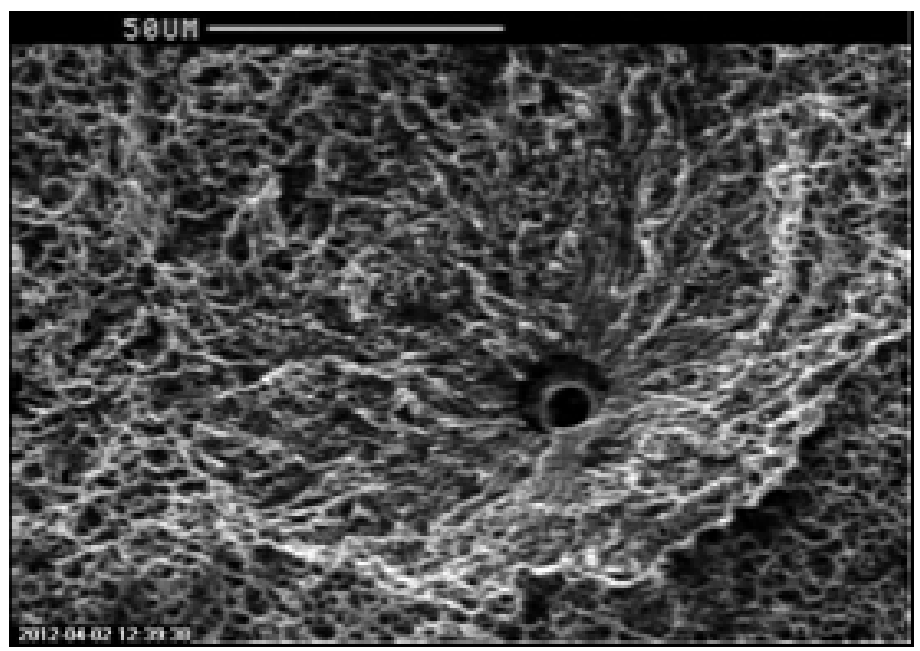

Fig. 9. "Fish eye" crack in 7CrMoVTiB10-10 steel weld metal after cathodic hydrogen charging

In the literature, cold cracking is often identified with hydrogen cracking [18]. It occurs when two of the following three factors are presents simultaneously: critical hydrogen content in the weld metal, high stresses (above the critical value) and susceptible microstructure (martensite or bainite, harder than $350 \mathrm{HV}$ ) [19]. Fourth factor is relatively low temperature. Table 2 shown that hardness of 7CrMoVTiB10-10 and S890QL1 steels welded joints, without post weld heat treatment, can be higher than $350 \mathrm{HV}$ (acceptance criterion). 
Table 2. Hardness of 7CrMoVTIB10-10 and S890QL1 steels welded joints (from the face of weld)

\begin{tabular}{|c|c|c|c|c|c|c|}
\hline & \multicolumn{3}{|c|}{ 7CrMoVTiB10-10 welded joint } & \multicolumn{3}{|c|}{ S8900L1 welded joint } \\
\hline Indentation number & 1 & 2 & 3 & 1 & 2 & 3 \\
\hline Base material & 198 & 192 & 196 & 296 & 302 & 297 \\
\hline Heat affected zone & 339 & 348 & 360 & 299 & 377 & 377 \\
\hline Fusion line & \multicolumn{3}{|c|}{373} & \multicolumn{3}{|c|}{341} \\
\hline Weld metal & 336 & 351 & 357 & 335 & 328 & 347 \\
\hline
\end{tabular}

\section{CONCLUSIONS}

High-strength steels are characterized by high mechanical properties, but weldability can be limited. The two steels tested are susceptible to hot cracking in the weld crater (7CrMoVTiB10-10) and cold cracking (7CrMoVTiB10-10 and S980QL1). In both cases intercrystalline and transcrystalline character of fractures was disclosed. In intercrystaline fracture, brittle broken-out sections from neighbouring grain surface were observed, characteristic of the hydrogen assisted cold cracking. Hardness of S890QL1 and 7CrMoVTiB10-10 welded joints can be higher than $350 \mathrm{HV}$ (acceptance criterion).

\section{ACKNOWLEDGEMENTS}

This research work was supported by the Polish Ministry of Science and Higher Education, contract no. 11.11.110.156. The authors are grateful to Dr. Eng Krzysztof Madej (Instytut Spawalnictwa in Gliwice, PL) for S890QL1 welded joints specimens.

\section{REFERENCES}

1. Ćwiek J.: Hydrogen enhanced-cracking of high-strength steel welded joints. Advances in Materials Science 4 (2008) 4-13.

2. Łabanowski J., Fydrych D., Rogalski G.: Underwater welding - A review. Advances in Materials Science 3 (2009) 11-22.

3. Kozak T. Resistance to cold cracking of welded joints made of P460NL1 steel. Advances in Materials Science 3 (2011) 20-27.

4. Fydrych D., Kozak T.: Underwater welded joint properties investigation. Advances in Materials Science 4 (2010) 4-14.

5. Muszka K., Majta J., Bienias Ł.: Effect of grain refinement on mechanical properties of microalloyed steels. Metallurgy and Foundry Engineering 2 (2006) 87-97.

6. Skubisz P., Sińczak J., Bednarek S., Łukaszek-Sołek A.: Effect of deformation degree on properties of forgings after thermomechanical treatment. Metallurgy and Foundry Engineering 2 (2006) 107-115.

7. Stefańska-Kądziela M., Majta J., Muszka K.: Effects of strain rate on work hardening of HSLA and Ti-IF steels. Metallurgy and Foundry Engineering 1 (2006) 19-29. 
8. Fydrych D., Łabanowski J., Rogalski G.: Weldability of high strength steels in wet welding conditions. Polish Marine Research 2 (2013) 67-73.

9. ASM Handbook Volume 01: Properties and Selection: Irons, Steels, and High-Performance Alloys. ASM International. 1990

10. EN 10025-6 Hot rolled products of structural steels - Technical delivery conditions for flat products of high yield strength structural steels in the quenched and tempered condition.

11. EN 10216-2 Seamless steel tubes for pressure purposes - Technical delivery conditions - Nonalloy and alloy steel tubes with specified elevated temperature properties

12. PN-EN ISO 4063 Welding and allied processes - Nomenclature of processes and reference numbers.

13. Adamiec J.: Hot Cracking of welded joints of the 7CrMoVTiB10-10 steel. IOP Conf. Ser.: Mater. Sci. Eng. 22 (2011) 1-11.

14. PN-EN ISO 5817 Welding - Fusion-welded joints in steel, nickel, titanium and their alloys (beam welding excluded) - Quality levels for imperfections.

15. Tasak E., Ziewiec A., Adamiec J.: Influence of hydrogen on welded joint cracking in bainitic and microalloyed steels. Metallurgy - Metallurgical Engineering News 4 (2008) 170-176 (in Polish).

16. Ziewiec A., Pańcikiewicz K., Tasak E.: Cracking in the welds metal of 7CrMoVTiB10-10 (T24) steel during welding, commissioning and operating of power units. Welding Technology Review 5 (2012) 2-7 (in Polish).

17. Adamiec J.: Cracking of welded joints made from 7CrMoVTiB10-10 steel. Proc. 2nd Int. Conf. Power welding, Ostaniec, Kroczyce, 2011, 7-19 (in Polish).

18. Kou S.: Welding Metallurgy, Wiley-Interscience, Hoboken, New Jersey, 2003.

19. Tasak E.: Welding Metallurgy, Jak, Kraków, 2008 (in Polish). 